\title{
A STUDY ON EVALUATION OF APPROPRIATE USAGE OF FRESH FROZEN PLASMA (FFP)
}

Dr. V. Geeta, Dr. I. Srilakshmi, Dr. A. Krishnayya, Dr. Lakshmi, Dr. Poornima, Dr. O. Shravan Kumar, Dr. P. Jijiya Bai
1. Assistant Professor, Department of Pathology, Gandhi Medical College, Secunderabad, AP.
2. Assistant Professor, Department of Pathology, Gandhi Medical College, Secunderabad, AP.
3. Assistant Professor, Department of Pathology, Gandhi Medical College, Secunderabad, AP.
4. Blood bank Medical Officer, Gandhi Medical College, Secunderabad, AP.
5. Post Graduate Student, Department of Pathology, Gandhi Medical College, Secunderabad, AP.
6. Professor \& HOD, Department of Pathology, Gandhi Medical College, Secunderabad, AP.

\section{CORRESPONDING AUTHOR-}

Dr. V. Geeta,

Assistant Professor,

Department of Pathology,

Gandhi Medical College,

Secunderabad, AP.

Email id-geetavoolapalli@gmail.com

\begin{abstract}
:
The term FFP refers to the fluid portion of 1 unit of human blood that has been centrifuged, separated \& frozen solid at $-18^{\circ} \mathrm{C}$ or colder within $8 \mathrm{hrs}$ of collection. The indications for transfusing FFP are very limited, as it can cause unpredictable adverse reactions. A retrospective study of FFP transfusion was carried out at the blood bank-Gandhi Medical College for a period of 6 months; i.e January 2011-July 2011 for various indications. We evaluated 840 patients who received 1534 units of FFP and classified them as appropriate, clinically appropriate and inappropriate. In our study appropriate and clinically appropriate transfusions of FFP were about 61\%- a good proportion of FFP transfusions were justified but 39\% were of without any appropriate indication.
\end{abstract}

KEY WORDS: Fresh Frozen Plasma, Centrifugation, Adverse Reactions

\section{INTRODUCTION:}

The use of FFP has increased due to multiple factors, possibly increased acceptance of the concept of component therapy.FFP contains the labile as well as stable components of the coagulation, fibrinolytic \& complement system; the proteins(that maintain oncotic pressure \& modulate immunity) and fats, carbohydrates \& minerals are present in concentrations similar to those in circulation. The most labile coagulation factors are preserved for $1 \mathrm{yr}$ if FFP is kept at $-30^{\circ}$ $\mathrm{C}$ or below. The FFP should be administered as soon as possible after thawing \& in any event within $12 \mathrm{hrs}$ if kept at $2-6^{\circ} \mathrm{C}$.

Journal of Evolution of Medical and Dental Sciences / Volume 1 / Issue 3 / July- Sept 2012 


\begin{tabular}{|l|}
\hline Contents of 1 unit of FFP prepared from $450 \mathrm{ml}$ of whole blood \\
\hline Plasma : $175-230 \mathrm{ml}$ \\
\hline All Coagulation Factors : 1 i.u/ml of each factor including factors V \\
\& VIII) \\
\hline Fibrinogen : $200-400 \mathrm{mgm}$ \\
\hline
\end{tabular}

\section{INDICATIONS OF FFP:}

$>$ Active bleeding,

$>$ Liver diseases

$>$ Disseminated intravascular coagulation (DIC)

$>$ Thrombotic Thrombocytopenic Purpura (TTP)

$>$ Coagulopathy in massive transfusion

$>$ Familial Factor $V$ deficiency

$>$ Deficiency of Factors II, VII, IX, X

$>$ Antithrombin III deficiency

$>$ Congenital or Acquired coagulation factor deficiency ${ }^{1}$

\section{DOSAGE OF FFP:}

About $10 \mathrm{ml} / \mathrm{Kg}$ body wt. Post transfusion assessment of levels of APTT, PT \& fibrinogen is done for monitoring the effect of FFP2 ${ }^{2}$. Plasma should be ABO compatible with the recipient blood.

\section{AIMS \& OBJECTIVES:}

Evaluation of appropriate usage of FFP in a period of 6 months (January 2011- June 2011) in Gandhi Hospital.

\section{MATERIALS \& METHOD:}

A Retrospective study was conducted at Gandhi Hospital Blood bank for a period of 6months (January 2011-june 2011). We evaluated 840 patients, who received 1534 units of FFP \& classified them as 1.Appropriate; 2.Inappropriate; 3 . Clinically appropriate.

Table: 1- SEX RATIO (M: F ratio- 1:1.5)

\begin{tabular}{|l|l|l|l|}
\hline SEX & MALE & FEMALE & TOTAL \\
\hline No. of patients & 382 & 458 & 840 \\
\hline$\%$ & $45.5 \%$ & $54.5 \%$ & $100 \%$ \\
\hline
\end{tabular}

Table: 2- AGE GROUP

\begin{tabular}{|l|c|c|c|c|c|c|c|c|}
\hline $\begin{array}{l}\text { AGE } \\
\text { GROUP }\end{array}$ & JAN & FEB & MARCH & APRIL & MAY & JUNE & TOTAL & JAN \\
\hline $0-20$ & 33 & 35 & 36 & 34 & 28 & 56 & 222 & $26.7 \%$ \\
\hline $21-40$ & 71 & 44 & 49 & 68 & 74 & 91 & 397 & $21-40$ \\
\hline $\begin{array}{l}41-60 \& \\
\text { ABOVE }\end{array}$ & 31 & 39 & 30 & 25 & 24 & 62 & 211 & 31 \\
\hline
\end{tabular}

Journal of Evolution of Medical and Dental Sciences / Volume 1 / Issue 3 / July- Sept 2012 
Table: 3- Guidelines-British Committee for Standard Hematology ${ }^{3}$

\begin{tabular}{|c|l|c|c|c|c|c|}
\hline SNO & $\begin{array}{l}\text { CLINICAL } \\
\text { CONDITIONS }\end{array}$ & $\begin{array}{l}\text { TOTAL } \\
\text { REQUIREMENT }\end{array}$ & $\begin{array}{l}\text { APPROPRI } \\
\text { ATE }\end{array}$ & $\begin{array}{l}\text { CLINICALY } \\
\text { APPROPRIATE }\end{array}$ & $\begin{array}{l}\text { INAPPROP } \\
\text { RIATE }\end{array}$ & $\%$ \\
\hline 1. & Liver Diseases & $\mathbf{1 5 2}$ & --- & $\mathbf{1 5 2}$ & ---- & $\mathbf{1 8 \%}$ \\
\hline $\mathbf{2 .}$ & DIC & $\mathbf{8 4}$ & --- & $\mathbf{8 4}$ & ---- & $\mathbf{1 0 \%}$ \\
\hline $\mathbf{3 .}$ & Hemophilia & $\mathbf{1 6 8}$ & $\mathbf{1 6 8}$ & ---- & ---- & $\mathbf{2 0 \%}$ \\
\hline $\mathbf{4 .}$ & Sepsis + Burns & $\mathbf{1 6 8}$ & $\mathbf{6 0}$ & ---- & $\mathbf{1 0 8}$ & $\mathbf{2 0 \%}$ \\
\hline $\mathbf{5 .}$ & $\begin{array}{l}\text { Cardiac } \\
\text { surgeries }\end{array}$ & $\mathbf{1 6 8}$ & ---- & --- & $\mathbf{1 6 8}$ & $\mathbf{2 0 \%}$ \\
\hline $\mathbf{6 .}$ & Snakebite & $\mathbf{8 0}$ & $\mathbf{5 0}$ & ---- & $\mathbf{3 0}$ & $\mathbf{9 . 5 \%}$ \\
\hline 7. & Others & $\mathbf{2 0}$ & ---- & ---- & --- & $\mathbf{2 . 5 \%}$ \\
\hline 8. & Total & 840 & 278 & 236 & 306 & \\
\hline
\end{tabular}

Table: 4- Total patients-840 ; Total units-1534

\begin{tabular}{|l|c|c|c|c|c|c|c|c|}
\hline $\begin{array}{l}\text { BLOOD } \\
\text { GROUP }\end{array}$ & O+ve & B+ve & AB+ve & A+ve & O-ve & A-ve & B-ve & AB-ve \\
\hline $\begin{array}{l}\text { No. of } \\
\text { Patients }\end{array}$ & 338 & 227 & 48 & 168 & 13 & 6 & 20 & 2 \\
\hline Percentage & $\begin{array}{l}40.9 \\
\%\end{array}$ & $\begin{array}{l}27.3 \\
\%\end{array}$ & $5.9 \%$ & $20 \%$ & $1.7 \%$ & $0.9 \%$ & $2.8 \%$ & $0.5 \%$ \\
\hline
\end{tabular}

\section{RESULTS:}

- Total patients who received FFP are 840, out of which males were 382 and females we 558 (table:1)

- Age group ranging from 0-20 years constitute $26.4 \%$; $21-40$ years $47.2 \%$; $41-60$ years $26.2 \%$ (table: 2 )

- Depending upon the conditions patients received FFP have been divided into 8 groups according to the guidelines provided by British Committee for Standard Hematology ${ }^{3}$ (table:3)

- Out of 840 patients, conditions like liver diseases, disseminated intravascular coagulation are clinically appropriate (where there is active bleeding leading to coagulopathy) and hemophilia, sepsis, burns, rheumatic heart diseases, snake bite and shock are considered to be appropriate (the term appropriate is limited to the treatment of coagulation protein deficiency, for which specific factor concentrates are un available or undesirable)-(table:3)

- No.of units of FFP transfused are 1534 in six months period. Of this $40.9 \%$ are transfused to 0 positive blood group (table: 4 ).

\section{DISCUSSION:}

$>$ FFP is efficacious for treatment of Deficiencies of factors II, V, VII, IX, X \& XI.

$>$ Reversal of warfarin effects: Patients who are anticoagulated with warfarin are deficient in functional vitamin $\mathrm{K}$ dependent coagulation factors II, VII, IX, X as well as protein C \& S. FFP can be used to achieve immediate hemostasis. 
> Massive Blood Transfusion: In patients with documented blood clotting abnormalities, prolonged APTT, INR after huge blood loss requiring 4 or more units of packed red cellsFFP is commonly recommended.

$>$ FFP can be used as a source of Antithrombin III in patients who are deficient of this inhibitor \& undergoing surgery or who require heparin for the treatment of thrombosis.

$>$ FFP useful in infants with secondary immunodeficiency associated with severe protein losing enteropathy, FFP can be used as a source of immunoglobulin for children \& adults with human immunodeficiency.

$>$ FFP is used in treatment of Thrombotic thrombocytopenic purpura.

\section{ASSOSIATED RISKS:}

- Anaphylactoid reactions

- Alloimmunisation

- Transfusion related acute lung injury (TRALI): antibodies against the patients granulocytes may cause leucocyte aggregation in pulmonary vessels leading to TRALI ${ }^{4}$

- Increase in infections

- Excess usage-Hypervolemia \& cardiac failure (The guidelines set by British Committee for Standard Hematology was followed in our study). ${ }^{3}$

Approximately 60\% FFP used are inappropriate according to Kakkar et al 5, but clinically apparent cases like liver diseases, coronary bypass surgeries reduced the inappropriate usage to $28 \%$. Severe liver disease $e^{6,7} \mathbf{8}$ is one of the most common clinical indications for transfusion of FFP. Patients with liver diseases have several abnormalities that can lead to bleeding like coagulopathy, Disseminated Intravascular Coagulation (DIC), Thrombosis. According to Consten et al9 \& LA Harker et al ${ }^{\mathbf{1 0}}$ in cardiac surgery ${ }^{\mathbf{1 1}}$ post operative bleeding due to residual effects of heparin may be corrected with transfusion of FFP.

\section{CONCLUSION:}

In our study appropriate \& clinically appropriate transfusions of FFP were about $61 \%$. It is desirable that educational programmes be arranged for doctors regarding appropriate usage of FFP.

Blood bank associations \& Hematologists should more firmly adhere to the guidelines.

In our institution 61\%, a good proportion of FFP transfusions were justified and 39\% were used without any appropriate indications.

\section{ACKNOWLEDGEMENT:}

I extend my special thanks to all the technical staff off blood bank and the personnel of record room of Gandhi Hospital for helping me in collecting the necessary data.

\section{REFERENCES:}

1. NIH consensus conference: Fresh frozen plasma: indications and risk JAMA1985; 253:5513.

2. Snyder AJ, Gotschall JL and Menitove JE. Why is fresh frozen plasma transfused? Transfusion1986; 26:107-12.

Journal of Evolution of Medical and Dental Sciences / Volume 1 / Issue 3 / July- Sept 2012 
3. British Committee for standards in Hematology, blood transfusion Task force. Guidelines for the use of Fresh frozen plasma, cryoprecipitate and cryo supernatant.TransfusionMed1992; 2:57-63.

4. Nordhagen R, Conradi M, Dromtort SM. Pulmonary reaction associated with transfusion of plasma containing anti-Vb. VOXSANG. 1986; 5:'102-8 (Pubmed)

5. Kakkar N, Kaur R and Dhanoa J. Improvement in fresh frozen plasma transfusion practice: results of an outcome audit. Transfus Med 2004; 14231-5.

6. Schofield WN, Rubin GL and Dean MG. Appropriateness of platelet, fresh frozen plasma and cryoprecipitate transfusion in New South Wales public hospital. Med J Aust 2003; 178:11721.

7. Spector I, Corn M and Ticktin HE. Effect of plasma transfusion on the prothrombin time and clotting factors in liver disease. Eng J Med 1966; 275: 1032-7.

8. Mannucci PM, Franchi F, Dioguardi N. Correction of abnormal coagulation in chronic liver disease by combined use of fresh frozen plasma and prothrombin complex concentrates. Lancet 1976; 2: 542-5.

9. Consten E, Henny CP, Eijsman L, Donglemant DA, Van Oers MH. The routine use of fresh frozen plasma in operations with coronary bypass surgery is not justified. J thorac Cardiovasc Surg 1996; 112:162-7.

10. LA Harker, TW Malpass, HE Branson, EA 2d Hessel and SJ Slichter. Mechanism of abnormal bleeding in patients undergoing coronary bypass surgeries. Acquired transient platelet dysfunction associated with selective Alpha granule release. Blood 1980; 56: 824-34.

11. Wilhelmi M, Franke U, Cohmert T, Weber P, Kaukemuller J, Fisher S, et al. Coronary artery by pass grafting surgery with out the routine application of blood products: Is it feasible? Eur J Cardiothorac Surg 2001; 19: 657-61 